\title{
Publication Productivity in Information Systems 2003-2007: A Focus on the 'Basket of Six' and the Pacific Asia Region
}

\author{
Aleck C. H. Lin \\ Australian National University \\ Canberra, ACT, 0200, Australia \\ Aleck.Lin@anu.edu.au \\ Shirley Gregor \\ Australian National University \\ Canberra, ACT, 0200, Australia \\ Shirley.Gregor@anu.edu.au
}

\begin{abstract}
This study examines the publication productivity of researchers in information systems (IS), with special emphasis on the Pacific Asia region. A scientometric analysis was performed covering the years 2003 to 2007, using articles from six premier IS journals: the 'Basket of Six' journals proposed by the Association for Information Systems. The authors with highest productivity were identified. Analysis by region for authors with high productivity showed a relationship between the region in which the researcher was based and the region in which the journals were published. Interestingly, publications by leading researchers in the Pacific Asia region were split almost evenly between North American and European outlets. Comparison with prior studies reinforces the importance of including journals with a diverse geographic base in studies of international productivity. The study shows increasing support for and development of quality journals with a regional base, such as the Pacific Asia Journal of the Association for Information Systems, is indicated.
\end{abstract}

Keywords: publication productivity, information systems, information systems research, scientometrics, the Pacific Asia region. 


\section{Introduction}

A number of contemporary studies have provided analyses of information systems (IS) research output and the impact of IS research. Notably, Lowry et al. (2007) provided an analysis of the leading institutions, faculty and articles, in terms of the citations that research papers received. Huang and Hsu (2005) examined the productivity of researchers and institutions from 1999 to 2003 in terms of numbers of papers published. A distinguishing feature of many of these studies is that they study publications in premier journals that are North American based. Unsurprisingly, results tend to show North American scholars and institutions as ranking highly. In the Lowry et al. (2007) study, for example, no institutions outside North America appeared in the top 25 in terms of research impact.

With the growth of Information Systems in regions outside North America, it is timely to consider alternative methods of studying productivity and, in particular, to provide comparisons within geographical regions. Each region has its own set of contextual factors that influence preferred publishing outlets and productivity. The geographic base of the basket of journals used in analyses of productivity can influence the results of the analysis, as shown by Gallivan and Benbunan-Fich (2007). The current study uses a basket of journals that is more diverse than in the case of many prior studies, in that it includes journals with a European base. In addition, it provides analysis specifically for the Pacific Asia region to mark the inaugural issue of the Pacific Asia Journal of the Association for Information Systems (PAJAIS).

The journal set chosen for analysis is the 'Basket of Six' journals recommended by the Association for Information Systems (AIS), namely: European Journal of Information Systems, Information Systems Journal, Information Systems Research, Journal of the Association for Information Systems, Journal of Management Information Systems, and
Management Information Systems Quarterly. These six IS journals were adopted in a formal statement by the 'Senior Scholars Forum' in April 2007 (AIS 2008') as representing topical, methodological, and geographic diversity in IS research. Moreover, the journals have common characteristics: 'the review processes are stringent, editorial board members are widely-respected and recognized, and there is international readership and contribution' (AIS $2008^{2}$ ). To our knowledge, no study as yet has used this basket of journals in researcher productivity analysis. It has been used in this study as it provides a relatively encompassing view of patterns of publication productivity. Further, the fact that the AIS as the peak international organization for IS has given this set of journals its imprimatur means that this set of six journals is likely to gain increasing validity as the internationally recognised set of journals by which researcher productivity is assessed.

The aim of the current study was to:

(1) investigate the publication productivity of IS researchers using the 'Basket of Six' journals; and

(2) consider patterns of publication by region and for the Pacific Asia region in particular.

\section{Prior Work}

This section reviews prior empirical studies of IS researchers' publication productivity in IS journals. The literature concerning publication productivity in the Pacific Asia region and regions outside North America is specifically noted.

Recent studies (Gallivan and Benbunan-Fich 2007, Huang and Hsu 200, Lowry et al. 2007) provide good coverage of studies assessing IS research and we will not repeat their literature overviews here. We will, however, note the findings of these recent papers. Table 1 shows the journals used in analysis in these studies.

Huang and Hsu (2005) focussed on 
publication productivity of IS researchers and institutions based on articles published in 12 journals from 1999-2003. Their results showed five non-North American universities in the top 31 institutions: City University of Hong Kong, Hong Kong University of Science and Technology, National University of Singapore, Korean Advanced Institute of Science and Technology and University of Hong Kong. A major increase in representation of Asian universities was noted, compared with prior studies (Athey and Plotnicki 2000, Im et al. 1998). More faculty from non-North American universities are also represented in the list of the top 30 most productive faculty. Four faculty in Pacific Asia were in this group: Patrick Chau, Bernard Tan, Kar Yan Tam and Kwok Kee Wei (K. K. Wei).

Lowry et al. (2007) provide an assessment of institutions, faculty and articles from just three journals and used citation analysis of the articles appearing from 1990-2004. Their study found that institutions outside North America were under-represented in the leading institutions. No institution outside North America was listed in the top 25 institutions. Five non-North American institutions appeared in the top 50 when at least one of their several ranking methods was utilised. These five included National University Singapore and Melbourne University from Pacific Asia. The authors questioned whether, given this pattern of findings, the three journals they had chosen for their sample 'basket' were truly international and whether they 'adequately represented all major forms of research published by IS academics worldwide' (Lowry et al. 2007, p. 148).

\begin{tabular}{|c|c|c|c|}
\hline Huang and Hsu (2005) & Lowry et al (2007) & $\begin{array}{c}\text { Gallivan and } \\
\text { Benbunan-Fich (2007) }\end{array}$ & This Study (2008) \\
\hline $\begin{array}{c}\text { Period of study } \\
1999-2003\end{array}$ & $\begin{array}{c}\text { Period of study } \\
2000-2004\end{array}$ & $\begin{array}{c}\text { Period of study } \\
1999-2003\end{array}$ & $\begin{array}{c}\text { Period of study } \\
2003-2007\end{array}$ \\
\hline $\begin{array}{l}\text { Communications of the } \\
\text { ACM } \\
\text { Decision Sciences } \\
\text { Decision Support Systems } \\
\text { Harvard Business Review } \\
\text { IEEE Transactions on } \\
\text { Software Engineering } \\
\text { Information \& Management } \\
\text { Information Systems } \\
\text { Research } \\
\text { Journal of Management } \\
\text { Information Systems } \\
\text { Journal of AIS } \\
\text { Management Science } \\
\text { MIS Quarterly } \\
\text { Sloan Management } \\
\text { Review }\end{array}$ & $\begin{array}{l}\text { Information Systems } \\
\text { Research } \\
\text { Management Science (IS } \\
\text { articles only) } \\
\text { MIS Quarterly }\end{array}$ & $\begin{array}{l}\text { Data Base for Advances in } \\
\text { Information Systems } \\
\text { Decision Sciences } \\
\text { Decision Support Systems } \\
\text { European Journal of } \\
\text { Information Systems } \\
\text { IEEE Transactions on } \\
\text { Engineering } \\
\text { Management } \\
\text { Information \& Management } \\
\text { Information Systems } \\
\text { Journal } \\
\text { Information Systems } \\
\text { Research } \\
\text { Information Technology \& } \\
\text { People (ITP) } \\
\text { Journal of Management } \\
\text { Information Systems } \\
\text { Journal of Strategic } \\
\text { Information Systems } \\
\text { (JSIS) } \\
\text { MIS Quarterly }\end{array}$ & $\begin{array}{l}\text { European Journal of } \\
\text { Information Systems } \\
\text { (EJIS) } \\
\text { Information Systems } \\
\text { Journal (ISJ) } \\
\text { Information Systems } \\
\text { Research (ISR) } \\
\text { Journal of the AIS (JAIS) } \\
\text { Journal of Management } \\
\text { Information Systems } \\
\text { (JMIS) } \\
\text { MIS Quarterly (MISQ) }\end{array}$ \\
\hline
\end{tabular}


A more inclusive approach was adopted by Gallivan and Benbunan-Fich (2007), who argued for the inclusion of journals outside North America in productivity studies and chose a more geographically balanced set of journals for their study. Four European journals were included (EJIS, ISJ, ITP and JSIS) and only research contributions were counted, with editorials, 'issues and opinions' and so forth ignored. The 240 authors who had published three or more articles in the period 1999-2003 were isolated for further analysis. Of this sample, $72.1 \%$ were based in North America, $13.3 \%$ in Europe and $14.6 \%$ in Pacific Asia. The list of the 'top 32' most productive authors included five authors from Asia (Patrick Chau, Bernard Tan, Kar Yan Tam, Thompson Teo and Robert Davison) and four women. The comparison of the results of this study with the Huang and Hsu (2003) study, which was for the same period and also covered 12 journals, but no European journals, was interesting. Huang and $\mathrm{Hsu}$ had no European scholars in their 'top 30' list. Gallivan and Benbunan-Fich's top 30 list included four authors from Europe and five authors from Asia. The conclusion is that choosing a sample of journals which included European journals meant that more Europeans were included in the ranking of leading researchers. Note that neither study included journals outside North America and Europe and, perhaps not surprisingly, a similar but small number of researchers from the Pacific Asia region ranked highly in both studies.

A limited number of studies have focussed on researcher productivity in the Pacific Asia region. A study by Khalifa and Ning (2008) observed the changes in IS research productivity and impact from 1995 to 2004. Khalifa and Ning found that 'Asian institutions, ..., are becoming more competitive. The number of Asian universities listed in the top 20 increased from three in the first period (1995 - 1999) to five in the second (2000 - 2004) for productivity and from one to two for impact' (Khalifa and Ning 2008, p.92). This finding indicates that academics in the Pacific Asia region are increasingly involved in global IS research. Zuo et al. (2008) consider 'the input side' of information systems research in Chinese universities from 2001 to 2005. However, they found that 'Surprisingly, emphasis on quality of publication has not significantly influenced researchers' effort yet' (Zuo et al. 2008, p.925). What these studies suggest in total is that although research productivity in Pacific Asia appears to be increasing, it is still underrepresented in lists of leading institutions and researchers compared with North America.

A similar situation has been noted when publishing by European researchers is compared with that of their U.S. counterparts. Lyytinen et al. (2007, p.317) have proposed seven reasons why researchers in the old world (the European region) faced difficulties in publishing high impact IS studies: (i) the lack of appreciation of the article genre; (ii) weak publishing cultures; (iii) inadequate Ph.D. preparation for article publishing; (iv) weak reviewing practices; (v) poorer command of research methods; (vi) poorer understanding of the reviewing protocols, and (vii) institutional shaping of research funding.

It is believed that researchers in the Pacific Asia region could be encountering similar conditions. In this study we explore productivity in Pacific Asia specifically, allowing 'like to be compared with like'. The results will be useful to faculty who wish to compare productivity with others researching in similar conditions and for institutions looking for data for benchmarking purposes.

\section{Method}

In this study we used an article count method to assess research performance, wherein a subset of journals (a 'basket') was chosen and the number of times a given author had published in each journal was counted. This method has been used in a number of other studies (e.g., Gallivan and Benbunan-Fich 2007, Huang and Hsu 2005) although it suffers from a limitation in that equal weight is given to articles regardless of their research impact. An alternative is citation analysis, 
where the impact of each article is assessed in terms of how widely the paper is cited. Lowry et al. (2007) used this method, although it also has disadvantages and gives less weight to articles that have appeared recently (see Clarke 2003). All methods suffer from disadvantages and results are liable to differ widely depending on the basket of journals chosen, the methods used to analyse productivity and the time period of the study. While acknowledging these limitations, we chose the article count method, as it has been widely used elsewhere and it allowed us to study recent publishing patterns. Further, we were able to include Journal of the Association for Information Systems in our basket, a journal that is new and for which citation analysis would not yield representative data.

\section{IS Journal Basket}

As indicated earlier, we used the AIS 'Basket of Six' as the subset of journals chosen for the study: European Journal of Information Systems (EJIS), Information Systems Journal (ISJ), Information Systems Research (ISR), Journal of the Association for Information Systems (JAIS), Journal of Management Information Systems (JMIS), and Management Information Systems Quarterly (MISQ). These six journals have been consistently ranked as influential general IS journals in the field by IS journal ranking studies from 2003 to 2008 (Peffers and Tang
2003, Lowry et al. 2004, Rainer and Miller 2005, ACPHIS 2008, ABDC 2008) (see Table 2). Three IS journals, MISQ, ISR, and JMIS, are consistently ranked in the top three positions. JAIS and ISJ are not consistently ranked in some studies, although they are high-quality journals and are considered ' $A$ ' journals by an increasing number of institutions (ACPHIS 2008, ABDC 2008). EJIS is published by the Macmillan Group and has strong support and respect within the European IS community (Lyytinen et al. 2007).

Table 3 provides additional information for the 'Basket of Six' journals from the ISI Journal Citation Reports (Thomson 2008 ${ }^{1,2,3}$ ). Four of the journals have an 'impact factor' (cites to recent articles/number of recent published articles) greater than 1.00 .

\section{Credit for Publications}

A number of methods can be used to give credit for authorship (see Im et al. 1998). In this study we employed two methods. The first method is the adjusted count, where the count for each publication is adjusted by the number of authors. For example, in the case of a paper with two authors, each author is given a count of 0.50 . The second method is the normal count (or absolute count), where individual authors are given a count of 1.0 for each paper that carries their name, regardless of the number of authors. We have used the adjusted count method as our

\begin{tabular}{|c|c|c|c|c|c|}
\hline \multicolumn{7}{|c|}{ Table 2. Rankings of the 'Basket of Six' Journals } \\
\hline Journal & $\begin{array}{c}\text { Peffers and } \\
\text { Tang (2003) }\end{array}$ & $\begin{array}{c}\text { Lowry et al. } \\
(\mathbf{2 0 0 4 )}\end{array}$ & $\begin{array}{c}\text { Rainer and } \\
\text { Miller (2005) }\end{array}$ & $\begin{array}{c}\text { ACPHIS } \\
\mathbf{( 2 0 0 8 )}\end{array}$ & ABDC (2008) \\
\hline MISQ & 1 & 1 & 1 & $A^{+}$ & $A^{*}$ \\
\hline ISR & 2 & 2 & 2 & $A^{+}$ & $A^{*}$ \\
\hline JMIS & 3 & 3 & 3 & $A^{+}$ & $A^{*}$ \\
\hline JAIS & 9 & 12 & - & $A^{+}$ & $A^{*}$ \\
\hline ISJ & - & - & - & $A^{+}$ & $A^{*}$ \\
\hline EJIS & 4 & 11 & 6 & $A^{+}$ & $A^{*}$ \\
\hline $\begin{array}{l}\text { ACPHIS } \\
\text { ABDC }\end{array}$ & Australian Council of Professors and Heads of Information Systems \\
\hline
\end{tabular}




\begin{tabular}{|c|r|r|c|}
\hline \multicolumn{5}{|c|}{ Table 3. Impact of the 'Basket of Six' Journals } \\
\hline Journal & $\begin{array}{c}\text { Impact Factor in } \\
\mathbf{2 0 0 7}\end{array}$ & Total Cites in $\mathbf{2 0 0 7}$ & First Publication \\
\hline MISQ & 5.826 & 4,329 & 1977 \\
\hline ISR & 2.682 & 2,146 & 1990 \\
\hline JMIS & 1.867 & 1,861 & 1984 \\
\hline ISJ & 1.531 & 380 & 1991 \\
\hline EJIS & 0.712 & 503 & 1992 \\
\hline JAIS & - & - & 2000 \\
\hline
\end{tabular}

primary means for ranking, as otherwise there is 'double counting' (that is, a paper is counted twice if it has two authors). This method is problematic when comparing institutional and regional performance. For example, if all five authors of one paper belong to the same institution, that institution will receive a count of five for just one paper.

\section{Procedure}

All articles published in the target journals during the period 2003 to 2007 were entered into a purpose built database, producing a sample of 956 articles with 1,424 authors. Items that were not 'research' articles, such as editorials and book reviews, were identified and excluded from further analysis. However, 'Research Opinions' and 'Research Notes', as in MIS Quarterly, were retained. A total of 870 articles then remained for analysis (see Table 4).

Data on authorship and institutional affiliation were obtained directly from each article. The attribution to a region was made by the researchers and entered into the database. Three regions were distinguished for a researcher's location using the AIS categorisation (AIS 2008 ${ }^{1}$ ): Region 1 - North and South America; Region 2 - Europe and Africa; and Region 3 - Asia and Oceania. Each researcher was given just one location. Most researchers had not moved from one region to another over the time period, but if they had, they were allocated to the region they were in as shown in their affiliation on their most recent publication. A research assistant was employed to check the database to guard against data entry and coding errors.

Note that Gallivan and Benbunan-Fich (2007) used a bibliographic repository that was made available by a team of faculty and Ph.D. students at Georgia State University (Chua et al. 2002). Unfortunately our enquiries showed that this database was not current at the time of our study (Chua 2008, pers. comm.).

\section{Findings and Discussions}

This section discusses the major findings of this study: the leading $101^{1}$ researchers categorised by the three regions, the leading researchers in the Pacific Asia region and cross-regional publishing patterns.

\section{Analysis across Regions}

Appendix 1 shows the leading 101 researchers in terms of number of publications using the adjusted counts metric, analysed by region. In total these 101 researchers were an author or co-author for 452 of the 870 papers in our sample (51.95\%) and in adjusted count terms contributed 219.18 of the 870 papers (25.19\%). Most of these 101 researchers (69 persons) are

\footnotetext{
${ }^{1}$ We originally intended to select the top 100 leading researchers. Due to the same ranking (1.41) for the $97^{\text {th }}$ person to the 101st person, 101 persons were included.
} 


\begin{tabular}{|c|c|c|c|c|c|c|c|c|}
\hline \multirow{2}{*}{ Journal } & \multicolumn{2}{|c|}{ From } & \multicolumn{2}{|c|}{ To } & \multicolumn{3}{|c|}{ Article Types } & \multirow{2}{*}{$\begin{array}{c}\text { Total } \\
\text { Articles }\end{array}$} \\
\hline & Month & Year & Month & Year & Research & Editorial/Errata & Other & \\
\hline MISQ & Mar & 2003 & Dec & 2007 & 147 & 14 & 1 & 162 \\
\hline ISR & Mar & 2003 & Dec & 2007 & 98 & 16 & 7 & 121 \\
\hline JMIS & Winter & $2002-2003$ & Fall & 2007 & 192 & 2 & 0 & 194 \\
\hline JAIS & May & 2003 & Dec & 2007 & 112 & 2 & 3 & 117 \\
\hline ISJ & Jan & 2003 & Oct & 2007 & 88 & 0 & 0 & 88 \\
\hline EJIS & Mar & 2003 & Dec & 2007 & 233 & 20 & 21 & 274 \\
\hline \multicolumn{5}{|c|}{ Total Articles } & 870 & 54 & 32 & 956 \\
\hline
\end{tabular}

\begin{tabular}{|c|c|c|c|c|}
\hline \multicolumn{6}{|c|}{ Table 5. Analysis of the Leading Researchers by Region } \\
\hline & $\begin{array}{c}\text { North and South } \\
\text { America }\end{array}$ & $\begin{array}{c}\text { Europe and } \\
\text { Africa }\end{array}$ & Pacific Asia & Total \\
\hline $\begin{array}{c}\text { Total Publication Counts } \\
\text { (adjusted) }\end{array}$ & $\begin{array}{c}158.96 \\
(72.52 \%)\end{array}$ & $\begin{array}{c}52.41 \\
(23.91 \%)\end{array}$ & 7.81 & 219.18 \\
\hline $\begin{array}{c}\text { Total Publication Counts } \\
\text { (normal) }\end{array}$ & 349 & 88 & 15 & $(100.00 \%)$ \\
\hline $\begin{array}{c}\text { Number of Leading } \\
\text { Researchers }\end{array}$ & $(77.21 \%)$ & $(19.47 \%)$ & $(3.32 \%)$ & 452 \\
& 69 & 27 & 4 & $100.00 \%)$ \\
\hline
\end{tabular}

in Region 1 (North and South America). Twenty-eight researchers are in Region 2. Just four researchers are from the Pacific Asia region: two from Hong Kong and two from Australia.

Table 5 shows the relative proportions of research output. In terms of both normal counts and adjusted counts, Region 1 contributes more than 70\%, Region 2 approximately $20 \%$ and Region 3 less than $4 \%$. This result shows the relative proportion of research by leading researchers situated in Pacific Asia is quite low.

\section{Analysis within Region 3 - Pacific Asia}

As our focus is on productivity within the Pacific Asia region, a further selection was made to identify the leading researchers in that region. From the original list of authors of the 870 articles published in our timeframe in the basket of six, all authors who had an adjusted count of more than 0.5 publications and who are in the Asia Pacific were selected.
Table 6 shows the list of 47 leading researchers in the Asia Pacific who satisfied these criteria, with their current affiliations (as shown on the university website). Eight researchers score more than 1.00 adjusted count, 15 of them have an adjusted count of 1.00 , and 24 have an adjusted count between 0.99 and 0.53. (see Table 6).

\section{Region 3 Publishing Trends}

Table 7 demonstrates the publication productivity of these 47 Pacific Asia leading researchers in the five year period. Each name represents an authored or co-authored paper in that year (that is, a normal count) and the number followed represents the adjusted count. From 2003 to 2006, the publications in the Pacific Asia area increased by the adjusted count, although there is a slight drop from 2003 to 2004. Considering the normal count, from 2004 to 2007, the publications in the Pacific Asia area seem to have increased (from 16 to 22 and 


\begin{tabular}{|c|c|c|c|c|c|}
\hline Researcher & University & $\begin{array}{c}\text { Adjusted } \\
\text { Count }\end{array}$ & Researcher & University & $\begin{array}{l}\text { Adjusted } \\
\text { Count }\end{array}$ \\
\hline Tam, Kar Yan & $\begin{array}{l}\text { Hong Kong University of } \\
\text { Science and Technology }\end{array}$ & 2.16 & Arnott, David & Monash University, & 2.00 \\
\hline Gregor, Shirley & Australian National University & 2.00 & Wei, K. K. & City University of Hong Kong & 1.65 \\
\hline Scheepers, Rens & University of Melbourne & 1.33 & Love, Peter & Edith Cowan University & 1.19 \\
\hline Davison, Robert & City University of Hong Kong & 1.16 & Pan, Shan & National University of Singapore & 1.08 \\
\hline Chang, Hsin Hsin & $\begin{array}{l}\text { National Cheng Kung } \\
\text { University Taiwan }\end{array}$ & 1.00 & Clarke, Roger & Australian National University & 1.00 \\
\hline Doolin, Bill & $\begin{array}{l}\text { Auckland University of } \\
\text { Technology }\end{array}$ & 1.00 & Khalifa, Mohamed & City University of Hong Kong & 1.00 \\
\hline Ho, Shuk Yin & Australian National University & 1.00 & Lee, Sangjae & Sejong University Korea & 1.00 \\
\hline Lam, Wing & $\begin{array}{l}\text { Universitas } 21 \text { Global } \\
\text { Singapore }\end{array}$ & 1.00 & Sia, Siew Kien & $\begin{array}{l}\text { Nanyang Technological } \\
\text { University }\end{array}$ & 1.00 \\
\hline Pauleen, David & Victoria University of Wellington & 1.00 & Taylor, W Andrew & University of New South Wales & 1.00 \\
\hline Smith, Stephen & Monash University & 1.00 & Wang, Weiquan & University of Hong Kong & 1.00 \\
\hline Varey, Richard & University of Waikato & 1.00 & Yetton, Philip & University of New South Wales & 1.00 \\
\hline Weber, Ron & Monash University & 1.00 & Chau, Patrick & University of Hong Kong & 0.99 \\
\hline $\begin{array}{l}\text { Kankanhalli, } \\
\text { Atreyi }\end{array}$ & $\begin{array}{l}\text { National University of } \\
\text { Singapore }\end{array}$ & 0.99 & Tan, Bernard & National University of Singapore & 0.99 \\
\hline Thong, James & $\begin{array}{l}\text { Hong Kong University of } \\
\text { Science and Technology }\end{array}$ & 0.99 & Wang, Eric & $\begin{array}{l}\text { National Central University } \\
\text { Taiwan }\end{array}$ & 0.99 \\
\hline Ang, Soon & \begin{tabular}{|l|} 
Nanyang Technological \\
University Singapore
\end{tabular} & 0.91 & Burn, Janice & $\begin{array}{l}\text { Edith Cowan University } \\
\text { Australia }\end{array}$ & 0.83 \\
\hline Lee, Jae Nam & City University of Hong Kong & 0.83 & Soh, Christina & \begin{tabular}{|l|} 
Nanyang Technological \\
University Singapore \\
\end{tabular} & 0.83 \\
\hline Lee, Matthew & City University of Hong Kong & 0.75 & Png, Ivan & National University of Singapore & 0.75 \\
\hline Vessey, Iris & $\begin{array}{l}\text { University of Queensland } \\
\text { Australia }\end{array}$ & 0.70 & Huang, Lihua & Fudan University China & 0.66 \\
\hline Liang, Ting Peng & \begin{tabular}{|l|} 
National Sun Yat Sen \\
University Taiwan \\
\end{tabular} & 0.66 & Teo, Hock Hai & National University of Singapore & 0.66 \\
\hline Wei, Hsiao Lan & $\begin{array}{l}\text { National Taiwan University of } \\
\text { Science and Technology }\end{array}$ & 0.66 & Bock, Gee Woo & National University of Singapore & 0.58 \\
\hline Hui, Kai Lung & City University of Hong Kong & 0.58 & Koh, Christine & \begin{tabular}{|l|} 
Nanyang Technological \\
University Singapore
\end{tabular} & 0.58 \\
\hline Kwok, Chi Wai & City University of Hong Kong & 0.58 & Lee, Sang Yong & Hanyang University Korea & 0.58 \\
\hline Tuunanen, Tuure & University of Auckland & 0.58 & Xu, Sean & $\begin{array}{l}\text { Hong Kong University of } \\
\text { Science and Technology }\end{array}$ & 0.58 \\
\hline $\begin{array}{l}\text { Rosemann, } \\
\text { Michael }\end{array}$ & $\begin{array}{l}\text { Queensland University of } \\
\text { Technology }\end{array}$ & 0.53 & & & \\
\hline
\end{tabular}

23, then to 24), although from 2003 to 2004 there is a slight decrease. This converges with the study by Khalifa and Ning (2008), which indicates that the research impacts of the publications in the top journals are progressing in this region.

\section{Cross-regional Patterns}

We conducted further analysis to investigate publishing patterns by the author's regional location against the publishing home regions of each journal. The basket of six journals were categorised into North American Journals (MISQ, ISR, JMIS and JAIS) and European Journals (ISJ and EJIS). The adjusted publication counts for each of the 101 leading authors for each journal were then analysed by region.

Tables 8 and 9 show the publishing patterns for Region 1 (Americas) and Region 2 (Europe) researchers respectively. The publishing pattern is very marked. The majority of Region 1 researchers (82.62\%) on our list published in North American outlets 
(Table 9). In contrast, the majority of the Region 2 researchers $(74.95 \%)$ published in European-based journals.

We had to adopt a different strategy to analyse the publishing patterns of researchers in Pacific Asia. There were only four researchers from Region 3 in our list of
101 leading researchers and analysis of such a small sample would not be meaningful. Thus for Pacific Asia, we used the subsample of the 47 researchers in the Pacific Asia region who had an adjusted publication count of more than 0.50 . Table 10 shows the publishing patterns for these Region 3 researchers.

\begin{tabular}{|c|c|c|c|c|c|}
\hline Journal Year & 2003 & 2004 & 2005 & 2006 & 2007 \\
\hline MISQ & $\begin{array}{l}\text { Davison, Robert }(0.50) \\
\text { Teo, Hock Hai }(0.33) \\
\text { Wei, K. K. }(0.33) \\
\text { Yetton, Philip }(0.50)\end{array}$ & & $\begin{array}{l}\text { Bock, Gee Woo }(0.25) \\
\text { Kankanhalli, Atreyi }(0.33) \\
\text { Lee, Jae Nam }(0.25) \\
\text { Tan, Bernard }(0.33) \\
\text { Wei, K. K. }(0.33)\end{array}$ & $\begin{array}{l}\text { Gregor, Shirley }(1.00) \\
\text { Ho, Shuk Yin }(0.50) \\
\text { Soh, Christina }(0.33) \\
\text { Tam, Kar Yan }(0.50) \\
\text { Vessey, Iris }(0.50)\end{array}$ & $\begin{array}{l}\text { Ang, Soon }(0.25) \\
\text { Hui, Kai Lung }(0.33) \\
\text { Koh, Christine }(0.25) \\
\text { Lee, Sang Yong }(0.33) \\
\text { Teo, Hock Hai }(0.33) \\
\text { Yetton, Philip }(0.50) \\
\end{array}$ \\
\hline ISR & $\begin{array}{l}\text { Ang, Soon (0.33) } \\
\text { Png, Ivan }(0.50)\end{array}$ & $\begin{array}{l}\text { Ang, Soon (0.33) } \\
\text { Koh, Christine (0.33) } \\
\text { Lee, Jae Nam }(0.33) \\
\text { Tam, Kar Yan }(0.33) \\
\text { Thong, James }(0.33)\end{array}$ & $\begin{array}{l}\text { Ho, Shuk Yin (0.50) } \\
\text { Tam, Kar Yan (0.50) }\end{array}$ & $\begin{array}{l}\text { Tam, Kar Yan (0.50) } \\
\text { Vessey, Iris }(0.20)\end{array}$ & \\
\hline JMIS & $\begin{array}{l}\text { Huang, Lihua }(0.33) \\
\text { Thong, James }(0.33) \\
\text { Tuunanen, Tuure }(0.33)\end{array}$ & $\begin{array}{l}\text { Kwok, Chi Wai (0.33) } \\
\text { Pauleen, David (1.00) } \\
\text { Xu, Sean (0.25) }\end{array}$ & $\begin{array}{l}\text { Tam, Kar Yan (0.33) } \\
\text { Thong, James (0.33) }\end{array}$ & $\begin{array}{l}\text { Lee, Matthew }(0.50, \text { Spr }) \\
\text { Lee, Matthew }(0.25, \text { Fal }) \\
\text { Wang, Eric }(0.33, \text { Sum }) \\
\text { Wang, Eric }(0.33, \text { Fal }) \\
\text { Wei, Hsiao Lan }(0.33)\end{array}$ & $\begin{array}{l}\text { Davison, Robert }(0.33) \\
\text { Kankanhalli, Atreyi }(0.33) \\
\text { Lee, Sang Yong }(0.25) \\
\text { Liang, Ting Peng }(0.33) \\
\text { Hui, Kai Lung }(0.25) \\
\text { Png, Ivan }(0.25) \\
\text { Tan, Bernard }(0.33) \\
\text { Wang, Weiquan }(0.50) \\
\text { Wei, K. K. }(0.33) \\
\end{array}$ \\
\hline JAIS & $\begin{array}{l}\text { Khalifa, Mohamed }(0.50) \\
\text { Tan, Bernard }(0.33) \\
\text { Wei, K. K. }(0.33)\end{array}$ & $\begin{array}{l}\text { Kwok, Chi Wai }(0.25) \\
\text { Lee, Jae Nam }(0.25)\end{array}$ & $\begin{array}{l}\text { Chau, Patrick }(0.33) \\
\text { Wang, Weiquan }(0.50)\end{array}$ & $\begin{array}{l}\text { Clarke, Roger (1.00) } \\
\text { Sia, Siew Kien (0.50) } \\
\text { Weber, Ron }(1.00)\end{array}$ & $\begin{array}{l}\text { Gregor, Shirley }(0.50) \\
\text { Tuunanen, Tuure }(0.25)\end{array}$ \\
\hline ISJ & & \begin{tabular}{|l} 
Davison, Robert (0.33) \\
Doolin, Bill (1.00)
\end{tabular} & Love, Peter (0.20) & $\begin{array}{l}\text { Arnott, David (1.00) } \\
\text { Chang, Hsin Hsin (1.00) } \\
\text { Pan, Shan (0.25) }\end{array}$ & \\
\hline EJIS & $\begin{array}{l}\text { Burn, Janice (0.50) } \\
\text { Lee, Sangjae (1.00) } \\
\text { Pan, Shan }(0.50) \\
\text { Varey, Richard (1.00) } \\
\text { Xu, Sean (0.33) }\end{array}$ & \begin{tabular}{|l} 
Arnott, David (1.00) \\
Gregor, Shirley (0.50) \\
Smith, Stephen (1.00) \\
Taylor, W Andrew (1.00)
\end{tabular} & $\begin{array}{l}\text { Chau, Patrick (0.33) } \\
\text { Huang, Lihua (0.33) } \\
\text { Lam, Wing }(1.00) \\
\text { Love, Peter }(0.33, \text { Jun) } \\
\text { Love, Peter }(0.33, \text { Sep) } \\
\text { Pan, Shan }(0.33) \\
\text { Rosemann, Michael (0.33) } \\
\text { Wang, Eric (0.33) } \\
\text { Wei, Hsiao Lan }(0.33) \\
\text { Wei, K. K. }(0.33)\end{array}$ & $\begin{array}{l}\text { Bock, Gee Woo }(0.33) \\
\text { Kankanhalli, Atreyi }(0.33) \\
\text { Rosemann, Michael }(0.20) \\
\text { Scheepers, Rens }(0.33, \text { Jun }) \\
\text { Scheepers, Rens }(1.00, \text { Dec) }\end{array}$ & $\begin{array}{l}\text { Burn, Janice }(0.33) \\
\text { Chau, Patrick }(0.33) \\
\text { Khalifa, Mohamed }(0.50) \\
\text { Liang, Ting Peng }(0.33) \\
\text { Love, Peter }(0.33) \\
\text { Sia, Siew Kien }(0.50) \\
\text { Soh, Christina }(0.5)\end{array}$ \\
\hline Total - Adjusted & 7.97 & 7.56 & 8.15 & 12.21 & 8.46 \\
\hline Total - Normal & 17 & 16 & 22 & 23 & 24 \\
\hline
\end{tabular}

\section{Table 8. Publishing Patterns for Region 1 (Americas) Researchers} (69 Researchers with 349 papers)

\begin{tabular}{|c|c|c|c|c|c|c|c|}
\hline & \multicolumn{3}{|c|}{ North American Journals } & \multicolumn{2}{c|}{ European Journals } & \multirow{2}{*}{ Total } \\
\cline { 2 - 8 } & MISQ & ISR & JMIS & JAIS & ISJ & EJIS & 17.05 \\
\hline \multirow{2}{*}{ Adjusted Count } & $\begin{array}{c}37.35 \\
(23.50 \%)\end{array}$ & $\begin{array}{c}25.21 \\
(15.86 \%)\end{array}$ & $\begin{array}{c}42.05 \\
(26.45 \%)\end{array}$ & $\begin{array}{c}26.73 \\
(16.82 \%)\end{array}$ & $\begin{array}{c}10.57 \\
(6.65 \%)\end{array}$ & $\begin{array}{c}158.96 \\
(10.73 \%)\end{array}$ & $(100.00 \%)$ \\
\hline Total Adjusted Count & \multicolumn{4}{|c|}{$82.62 \%$} & \multicolumn{2}{c|}{$17.38 \%$} & $100.00 \%$ \\
\hline
\end{tabular}




\begin{tabular}{|c|c|c|c|c|c|c|c|}
\hline & \multicolumn{4}{|c|}{ North American Journals } & \multicolumn{2}{|c|}{ European Journals } & \multirow{2}{*}{ Total } \\
\hline & MISQ & ISR & JMIS & JAIS & ISJ & EJIS & \\
\hline Adjusted Count & $\begin{array}{c}5.31 \\
(10.13 \%)\end{array}$ & $\begin{array}{c}0 \\
(0.00 \%)\end{array}$ & $\begin{array}{c}1.66 \\
(3.17 \%)\end{array}$ & $\begin{array}{c}6.16 \\
(11.75 \%)\end{array}$ & $\begin{array}{c}13.89 \\
(26.50 \%)\end{array}$ & $\begin{array}{c}25.39 \\
(48.44 \%)\end{array}$ & $\begin{array}{c}52.41 \\
(100.00 \%)\end{array}$ \\
\hline Total Adjusted Count & \multicolumn{4}{|c|}{$25.05 \%$} & \multicolumn{2}{|c|}{$74.95 \%$} & $100.00 \%$ \\
\hline
\end{tabular}

\begin{tabular}{|c|c|c|c|c|c|c|c|}
\hline & \multicolumn{4}{|c|}{ North American Journals } & \multicolumn{2}{|c|}{ European Journals } & \multirow{2}{*}{ Total } \\
\hline & MISQ & ISR & JMIS & JAIS & ISJ & EJIS & \\
\hline Adjusted Count & $\begin{array}{c}7.97 \\
(17.57 \%)\end{array}$ & $\begin{array}{c}4.18 \\
(9.22 \%)\end{array}$ & $\begin{array}{c}7.87 \\
(17.35 \%)\end{array}$ & $\begin{array}{c}5.74 \\
(12.66 \%)\end{array}$ & $\begin{array}{c}3.78 \\
(8.34 \%)\end{array}$ & $\begin{array}{c}15.81 \\
(34.86 \%)\end{array}$ & $\begin{array}{c}45.35 \\
(100.00 \%)\end{array}$ \\
\hline Total Adjusted Count & \multicolumn{4}{|c|}{$56.80 \%$} & \multicolumn{2}{|c|}{$43.20 \%$} & $100.00 \%$ \\
\hline
\end{tabular}

\section{Conclusions}

In this study we investigated the publication productivity of researchers in IS, with a focus on the Pacific Asia region. An initial sample was formed by collecting data for all the authors and articles published in the AIS 'Basket of Six' journals from 2003 to 2007. A sub-sample was then created by selecting the 101 researchers who had the highest (adjusted) publication counts. The normal count of papers for this group ranged from 2 to 17. For this group, 69 researchers were from Region 1 (Americas), 27 from Region 2 (Europe-Africa) and 4 from Region 3 (Pacific Asia). A further sub-sample was drawn of all researchers in the Pacific Asia region who had an adjusted count of more than 0.50 , giving 47 researchers.

A cross-regional analysis indicated that publishing patterns vary a great deal by region. Region 1 researchers overwhelmingly publish in Region 1 journals and Region 2 researchers overwhelmingly publish in Region 2 journals. This finding is congruent with the observations of Gallivan and Benbunan-Fich (2007). The importance of comparing 'like-with-like' and assessing productivity with respect to a researcher's home region and the journals in that region is very marked.
Interestingly, the analysis of the output of the 47 researchers in Pacific Asia whose work was studied indicated that their work was more evenly distributed between Region 1 (56.80\%) and Region 2 (43.20\%). The Basket of Six contains no journals that are based in Pacific Asia and indeed there are few journals in this region that can aspire to a high placement in journal ranking exercises. Given the patterns we have observed of publication being related to the geographic location of both researchers and journals, we see a need for the support and promotion of more journals in the Pacific Asia region that can, with time, gain international recognition. The Pacific Asia Journal of the Association for Information Systems, with the support of the AIS and the IS community could grow into such a journal.

Our work here is subject to the usual limitations of such studies, in that we have chosen one basket of journals, an article count method rather than citation analysis, and one time period. Many top-tier IS journals (for example, Decision Support Systems and Journal of Information Technology) were not included. Thus, the samples of 'leading' researchers we have identified result from this method. Using different methods and a different set of journals would undoubtedly yield different samples. Our results should be interpreted accordingly. 


\section{References}

ABDC (Australian Business Deans Council) 2008, ABDC Journal List, Retrieved $7^{\text {th }} \quad$ August 2008 from http://www.abdc.edu.au/3.36.0.0.1.0.h tm

ACPHIS (Australian Council of Professors and Heads of Information Systems) 2008, IS Journal Ranking, Retrieved $7^{\text {th }} \quad$ August 2008 from http://www.acphis.org.au/index.php?o ption $=$ content\&task $=$ section\&id $=6 \&$ lte mid $=52$.

AIS $^{1}$ (Association for Information Systems) 2008, Regions, Retrieved $7^{\text {th }}$ August 2008 from http://home.aisnet.org/displaycommon .cfm?an=1\&subarticlenbr=8.

AIS $^{2}$ (Association for Information Systems) 2008, Senior Scholars' Basket of Journals, Retrieved $7^{\text {th }}$ August 2008 from

http://home.aisnet.org/displaycommon.c $\mathrm{fm}$ ? an $=1$ \&subarticlenbr=346.

Athey, S., and Plotnicki, J. (2000) "An Evaluation of Research Productivity in Academic IT," Communications of the Association for Information Systems 3, pp.1-20.

Chua, C. (2008) Personal Communication, $26^{\text {th }}$ August 2006, by E-mail.

Chua, C., L. Cao, K. Cousins, and D. W. Straub (2002) "Measuring Researcher-Production in Information Systems", Journal of the Association for Information Systems 3 (4), pp.145215.

Clarke, R. (2003) "An Exploratory Study of Information Systems Researcher Impact", Communications of the AIS 12, Article 22.

Gallivan, M. J. and Benbunan-Fich, R. (2007) "Analysing IS Research Productivity: An Inclusive Approach to Global IS Scholarship", European Journal of Information Systems, pp.36-53.

Huang, H. H. and Hsu, J. S. C. (2005) "An Evaluation of Publication Productivity in Information Systems: 1999 to 2003", Communications of the Association for Information Systems 15, pp.555564.

Im, K. S., Kim, K. Y., and Kim, J. S. (1998) "An Assessment of Individual and Institutional Research Productivity in MIS", Decision Line 29 (1), pp.8-12.

Khalifa, M. and Ning, K. (2008) "Demographic Changes in IS Research Productivity and Impact", Communications of the ACM 51 (4), pp.89-94.

Lowry, P. B., Karuga, G. G., and Richardson, V. J. (2007) "Assessing Leading Institutions, Faculty, and Articles in Premier Information Systems Research Journals", Communications of the Association for Information Systems 20, pp.142-203.

Lowry, P. B., Romans, D., and Curtis, A. (2004) "Global Journal Prestige and Supporting Disciplines: A Scientometric Study of Information Systems Journals," Journal of the Association for Information Systems 5 (2), pp.29-77.

Lyytinen, K., Baskerville, R., livari, J., and Te'eni, D. (2007) "Why the Old World cannot Publish? Overcoming Challenges in Publishing High-Impact IS Research", European Journal of Information Systems 16, pp.317-326.

Peffers, K. and T. Ya, (2003) "Identifying and Evaluating the Universe of Outlets for Information Systems Research: Ranking the Journals", Journal of Information Technology Theory and Application 5 (1), pp.63-84.

Rainer Jr., R. K. and Miller, M. D. (2005) "Examining Differences across Journal Rankings", Communications of the ACM 48 (2), pp. 91-94.

Thomson $\left(2008^{1}\right)$ Journal Citation Reports, Retrieved $7^{\text {th }}$ August 2008 from http://admin-

apps.isiknowledge.com/JCR/JCR?Poin tOfEntry=Home\&SID=W2N4@GPN7O $\mathrm{IH} 1 \mathrm{HoCeCF}$.

Thomson $\left(2008^{2}\right)$ Science Citation Index, Retrieved $7^{\text {th }}$ August 2008 from http://www.thomsonscientific.com/cgi- 
Pacific Asia Journal of the Association for Information Systems, Vol. 1, Iss. 1 [2009], Art. 7

Publication productivity in Information Systems/Lin \& Gregor

bin/jrnlst/jloptions.cgi?PC=K.

Thomson $\left(2008^{3}\right)$ Social Science Citation Index, Retrieved $7^{\text {th }}$ August 2008 from http://www.thomsonscientific.com/cgibin/jrnlst/jloptions.cgi?PC=J.
Zuo, M. Y., Mao, J. Y., and Lin, X. (2008) "Information Systems Research in Chinese Universities: An Examination of the Input Side", in Proceedings of the $12^{\text {th }}$ Pacific Asia Conference on Information Systems, PACIS 2008, Suzhou, China, pp.925-935. 


\section{Appendix I: The Leading 101 Researchers by Region (in terms of counts)}

\begin{tabular}{|c|c|c|c|c|c|c|c|}
\hline \multicolumn{8}{|c|}{ Region 1 - North and South America } \\
\hline Researcher & University & $\begin{array}{l}\text { Adjusted } \\
\text { Count }\end{array}$ & $\begin{array}{c}\text { Normal } \\
\text { Count }\end{array}$ & Researcher & University & $\begin{array}{c}\text { Adjusted } \\
\text { Count }\end{array}$ & $\begin{array}{c}\text { Normal } \\
\text { Count }\end{array}$ \\
\hline Benbasat, Izak & \begin{tabular}{|l|} 
University of \\
British Columbia
\end{tabular} & 7.74 & 17 & Lyytinen, Kalle & $\begin{array}{l}\text { Case Western } \\
\text { Reserve } \\
\text { University }\end{array}$ & 5.41 & 13 \\
\hline Hirschheim, Rudy & $\begin{array}{l}\text { Louisiana State } \\
\text { University }\end{array}$ & 4.66 & 9 & Straub Jr, Detmar & $\begin{array}{l}\text { Georgia State } \\
\text { University }\end{array}$ & 4.65 & 9 \\
\hline Kauffman, Robert & $\begin{array}{l}\text { Arizona State } \\
\text { University }\end{array}$ & 4.15 & 11 & Silva, Leiser & $\begin{array}{l}\text { University of } \\
\text { Houston, }\end{array}$ & 4.08 & 7 \\
\hline Clemons, Eric & $\begin{array}{l}\text { University of } \\
\text { Pennsylvania }\end{array}$ & 3.65 & 8 & Baskerville, Richard & $\begin{array}{l}\text { Georgia State } \\
\text { University }\end{array}$ & 3.61 & 8 \\
\hline Riggins, Frederick & $\begin{array}{l}\text { University of } \\
\text { Minnesota }\end{array}$ & 3.16 & 5 & Gosain, Sanjay & $\begin{array}{l}\text { Capital Group } \\
\text { Companies, Inc. }\end{array}$ & 3.15 & 7 \\
\hline Pavlou, Paul & $\begin{array}{l}\text { University of } \\
\text { California at } \\
\text { Riverside }\end{array}$ & 3.08 & 7 & Whinston, Andrew & $\begin{array}{l}\text { University of } \\
\text { Texas at Austin }\end{array}$ & 3.07 & 9 \\
\hline Zmud, Robert & $\begin{array}{l}\text { University of } \\
\text { Oklahoma }\end{array}$ & 3.07 & 7 & Robey, Daniel & $\begin{array}{l}\text { Georgia State } \\
\text { University }\end{array}$ & 2.99 & 6 \\
\hline $\begin{array}{l}\text { Tanriverdi, } \\
\text { Huseyin }\end{array}$ & $\begin{array}{l}\text { University of } \\
\text { Texas at Austin }\end{array}$ & 2.83 & 4 & Kraemer, Kenneth & $\begin{array}{l}\text { University of } \\
\text { California, Irvine }\end{array}$ & 2.74 & 8 \\
\hline Galletta, Dennis & $\begin{array}{l}\text { University of } \\
\text { Pittsburgh }\end{array}$ & 2.66 & 7 & Gallivan, Michael & $\begin{array}{l}\text { Georgia State } \\
\text { University }\end{array}$ & 2.66 & 6 \\
\hline Keil, Mark & $\begin{array}{l}\text { Georgia State } \\
\text { University }\end{array}$ & 2.66 & 6 & Grover, Varun & $\begin{array}{l}\text { Clemson } \\
\text { University }\end{array}$ & 2.61 & 7 \\
\hline Zhu, Kevin & $\begin{array}{l}\text { University of } \\
\text { California }\end{array}$ & 2.58 & 6 & Light, Ben & $\begin{array}{l}\text { University of } \\
\text { Salford }\end{array}$ & 2.50 & 4 \\
\hline Subramani, Mani & $\begin{array}{l}\text { University Of } \\
\text { Minnesota }\end{array}$ & 2.50 & 4 & Gefen, David & $\begin{array}{l}\text { Drexel } \\
\text { University }\end{array}$ & 2.33 & 4 \\
\hline $\begin{array}{l}\text { Bhattacherjee, } \\
\text { Anol }\end{array}$ & $\begin{array}{l}\text { University of } \\
\text { South Florida }\end{array}$ & 2.16 & 5 & Oh, Wonseok & McGill University & 2.16 & 6 \\
\hline Mathiassen, Lars & $\begin{array}{l}\text { Georgia State } \\
\text { University }\end{array}$ & 2.08 & 5 & $\begin{array}{l}\text { Venkatesh, } \\
\text { Viswanath }\end{array}$ & $\begin{array}{l}\text { University of } \\
\text { Arkansas }\end{array}$ & 2.08 & 5 \\
\hline Dewan, Rajiv & $\begin{array}{l}\text { University of } \\
\text { Rochester }\end{array}$ & 2.07 & 6 & $\begin{array}{l}\text { Burton-Jones, } \\
\text { Andrew }\end{array}$ & $\begin{array}{l}\text { University of } \\
\text { British Columbia }\end{array}$ & 2.00 & 4 \\
\hline \begin{tabular}{|l} 
Davidson, \\
Elizabeth
\end{tabular} & \begin{tabular}{|l|} 
University of \\
Hawaii Manoa
\end{tabular} & 2.00 & 4 & \begin{tabular}{|l|} 
Dellarocas, \\
Chrysanthos
\end{tabular} & $\begin{array}{l}\text { University of } \\
\text { Maryland }\end{array}$ & 2.00 & 2 \\
\hline Fichman, Robert & $\begin{array}{l}\text { Boston College, } \\
\text { Carroll School } \\
\text { of Management }\end{array}$ & 2.00 & 2 & Galliers, Robert & Bentley College & 2.00 & 3 \\
\hline Levina, Natalia & $\begin{array}{l}\text { New York } \\
\text { University }\end{array}$ & 2.00 & 3 & Sambamurthy, V & $\begin{array}{l}\text { Michigan State } \\
\text { University }\end{array}$ & 1.99 & 5 \\
\hline Agarwal, Ritu & $\begin{array}{l}\text { University of } \\
\text { Maryland }\end{array}$ & 1.91 & 5 & $\begin{array}{l}\text { Choudhary, } \\
\text { Vidyanand }\end{array}$ & $\begin{array}{l}\text { University of } \\
\text { California }\end{array}$ & 1.83 & 3 \\
\hline Kirsch, Laurie & $\begin{array}{l}\text { University of } \\
\text { Pittsburgh }\end{array}$ & 1.83 & 3 & Stewart, Katherine & $\begin{array}{l}\text { University of } \\
\text { Maryland }\end{array}$ & 1.83 & 3 \\
\hline Gupta, Alok & $\begin{array}{l}\text { University of } \\
\text { Minnesota }\end{array}$ & 1.74 & 5 & Jiang, James & $\begin{array}{l}\text { University of } \\
\text { Central Florida }\end{array}$ & 1.74 & 6 \\
\hline
\end{tabular}


Pacific Asia Journal of the Association for Information Systems, Vol. 1, Iss. 1 [2009], Art. 7 Publication productivity in Information Systems/Lin \& Gregor

\begin{tabular}{|c|c|c|c|c|c|c|c|}
\hline King, William & $\begin{array}{l}\text { University of } \\
\text { Pittsburgh }\end{array}$ & 1.74 & 5 & Nunamaker Jr, Jay & $\begin{array}{l}\text { University of } \\
\text { Arizona }\end{array}$ & 1.69 & 6 \\
\hline Browne, Glenn & $\begin{array}{l}\text { Texas Tech } \\
\text { University }\end{array}$ & 1.66 & 4 & Sarker, Suprateek & \begin{tabular}{|l} 
Washington \\
State University
\end{tabular} & 1.66 & 4 \\
\hline Rai, Arun & $\begin{array}{l}\text { Georgia State } \\
\text { University }\end{array}$ & 1.65 & 5 & $\begin{array}{l}\text { Mukhopadhyay, } \\
\text { Tridas }\end{array}$ & $\begin{array}{l}\text { Carnegie Mellon } \\
\text { University }\end{array}$ & 1.57 & 5 \\
\hline $\begin{array}{l}\text { Bhargava, } \\
\text { Hemant }\end{array}$ & $\begin{array}{l}\text { University of } \\
\text { California }\end{array}$ & 1.50 & 3 & Chellappa, Ramnath & \begin{tabular}{|l} 
Emory \\
University, \\
Atlanta
\end{tabular} & 1.50 & 3 \\
\hline Dennis, Alan & $\begin{array}{l}\text { Indiana } \\
\text { University }\end{array}$ & 1.50 & 4 & Kettinger, William & $\begin{array}{l}\text { University of } \\
\text { Memphis }\end{array}$ & 1.50 & 3 \\
\hline King, John & $\begin{array}{l}\text { University of } \\
\text { Michigan }\end{array}$ & 1.50 & 3 & Larsen, Kai & $\begin{array}{l}\text { University of } \\
\text { Colorado at } \\
\text { Boulder }\end{array}$ & 1.50 & 2 \\
\hline Lee, Yang & $\begin{array}{l}\text { Northeastern } \\
\text { University }\end{array}$ & 1.50 & 2 & Lucas Jr, Henry & $\begin{array}{l}\text { University of } \\
\text { Maryland }\end{array}$ & 1.50 & 4 \\
\hline Nissen, Mark & \begin{tabular}{|l|} 
Naval \\
Postgraduate \\
School
\end{tabular} & 1.50 & 2 & Orlikowski, Wanda & \begin{tabular}{|l|} 
MIT's Sloan \\
School of \\
Management
\end{tabular} & 1.50 & 2 \\
\hline Paul, David & $\begin{array}{l}\text { University of } \\
\text { Denver }\end{array}$ & 1.50 & 2 & Rose, Gregory & $\begin{array}{l}\text { Washington } \\
\text { State University }\end{array}$ & 1.50 & 3 \\
\hline $\begin{array}{l}\text { Sundararajan, } \\
\text { Arun }\end{array}$ & $\begin{array}{l}\text { New York } \\
\text { University }\end{array}$ & 1.50 & 2 & Tiwana, Amrit & \begin{tabular}{|l} 
lowa State \\
University
\end{tabular} & 1.50 & 3 \\
\hline El Sawy, Omar & $\begin{array}{l}\text { University of } \\
\text { Southern } \\
\text { California } \\
\end{array}$ & 1.49 & 4 & Ghose, Anindya & $\begin{array}{l}\text { New York } \\
\text { University }\end{array}$ & 1.49 & 4 \\
\hline Byrd, Terry & \begin{tabular}{|l} 
Auburn \\
University, \\
Alabama
\end{tabular} & 1.41 & 4 & Davis, Fred & $\begin{array}{l}\text { University of } \\
\text { Arkansas }\end{array}$ & 1.41 & 4 \\
\hline Freimer, Marshall & $\begin{array}{l}\text { University of } \\
\text { Rochester }\end{array}$ & 1.41 & 4 & Markus, M & Bentley College & 1.41 & 4 \\
\hline Saunders, Carol & $\begin{array}{l}\text { University of } \\
\text { Central Florida }\end{array}$ & 1.41 & 4 & & & & \\
\hline \multicolumn{8}{|c|}{ Region 2 - Europe and Africa } \\
\hline Researcher & University & $\begin{array}{l}\text { Adjusted } \\
\text { Count }\end{array}$ & $\begin{array}{l}\text { Normal } \\
\text { Count }\end{array}$ & Researcher & University & $\begin{array}{c}\text { Adjusted } \\
\text { Count }\end{array}$ & $\begin{array}{l}\text { Norma } \\
\text { Count }\end{array}$ \\
\hline Mumford, Enid & $\begin{array}{l}\text { University of } \\
\text { Manchester }\end{array}$ & 3.00 & 3 & Avison, David & \begin{tabular}{|l|} 
ESSEC \\
Business School
\end{tabular} & 2.67 & 4 \\
\hline Sahay, Sundeep & $\begin{array}{l}\text { University of } \\
\text { Oslo }\end{array}$ & 2.66 & 5 & Siponen, Mikko & $\begin{array}{l}\text { University of } \\
\text { Oulu }\end{array}$ & 2.33 & 4 \\
\hline $\begin{array}{l}\text { Themistocleous, } \\
\text { Marinos }\end{array}$ & $\begin{array}{l}\text { Brunel } \\
\text { University }\end{array}$ & 2.28 & 5 & livari, Juhani & $\begin{array}{l}\text { University of } \\
\text { Oulu }\end{array}$ & 2.16 & 6 \\
\hline Irani, Zahir & $\begin{array}{l}\text { Brunel } \\
\text { University }\end{array}$ & 2.10 & 7 & Fitzgerald, Brian & $\begin{array}{l}\text { University of } \\
\text { Limerick }\end{array}$ & 2.08 & 4 \\
\hline D'Atri, Alessandro & $\begin{array}{l}\text { Centro Ricerca } \\
\text { Sistemi } \\
\text { Informativi }\end{array}$ & 2.00 & 2 & Gao, Ping & $\begin{array}{l}\text { University of } \\
\text { Manchester }\end{array}$ & 2.00 & 2 \\
\hline Stahl, Bernd & $\begin{array}{l}\text { De Montfort } \\
\text { University }\end{array}$ & 2.00 & 2 & Walsham, Geoff & $\begin{array}{l}\text { University of } \\
\text { Cambridge }\end{array}$ & 2.00 & 2 \\
\hline Whitley, Edgar & $\begin{array}{l}\text { London School } \\
\text { of Economics } \\
\text { and Political }\end{array}$ & 2.00 & 3 & $\begin{array}{l}\text { Heijden, Hans van } \\
\text { der }\end{array}$ & $\begin{array}{l}\text { University of } \\
\text { Surrey }\end{array}$ & 1.83 & 3 \\
\hline
\end{tabular}


Lin and Gregor: A Focus on the 'Basket of Six' and the Pacific Asia Region

Publication productivity in Information Systems/Lin \& Gregor

\begin{tabular}{|c|c|c|c|c|c|c|c|}
\hline & Science & & & & & & \\
\hline $\begin{array}{l}\text { Loebbecke, } \\
\text { Claudia }\end{array}$ & $\begin{array}{l}\text { University of } \\
\text { Cologne }\end{array}$ & 1.83 & 3 & Pries-Heje, Jan & \begin{tabular}{|l} 
The IT \\
University of \\
Copenhagen
\end{tabular} & 1.53 & 4 \\
\hline $\begin{array}{l}\text { Avgerou, } \\
\text { Chrisanthi }\end{array}$ & $\begin{array}{l}\text { University of } \\
\text { London }\end{array}$ & 1.50 & 2 & Butler, Tom & \begin{tabular}{|l|} 
University \\
College Cork
\end{tabular} & 1.50 & 2 \\
\hline Chiasson, Mike & $\begin{array}{l}\text { Lancaster } \\
\text { University } \\
\text { Management } \\
\text { School }\end{array}$ & 1.50 & 3 & Fitzgerald, Guy & $\begin{array}{l}\text { Brunel } \\
\text { University }\end{array}$ & 1.50 & 2 \\
\hline Introna, Lucas & \begin{tabular}{|l} 
Lancaster \\
University \\
Management \\
School
\end{tabular} & 1.50 & 2 & McGrath, Kathy & $\begin{array}{l}\text { Brunel } \\
\text { University }\end{array}$ & 1.50 & 2 \\
\hline Mingers, John & $\begin{array}{l}\text { University of } \\
\text { Kent }\end{array}$ & 1.50 & 2 & Oates, Briony & $\begin{array}{l}\text { University of } \\
\text { Teesside }\end{array}$ & 1.50 & 2 \\
\hline Pateli, Adamantia & $\begin{array}{l}\text { University of } \\
\text { Economics and } \\
\text { Business, } \\
\text { Athens }\end{array}$ & 1.50 & 2 & Soffer, Pnina & $\begin{array}{l}\text { University of } \\
\text { Haifa }\end{array}$ & 1.50 & 3 \\
\hline Kautz, Karlheinz & \begin{tabular}{|l|} 
Copenhagen \\
Business \\
School, \\
Copenhagen
\end{tabular} & 1.49 & 4 & Hanseth, Ole & $\begin{array}{l}\text { University of } \\
\text { Oslo }\end{array}$ & 1.45 & 3 \\
\hline \multicolumn{8}{|c|}{ Region 3 - Pacific Asia } \\
\hline Researcher & University & $\begin{array}{l}\text { Adjusted } \\
\text { Count }\end{array}$ & $\begin{array}{c}\text { Normal } \\
\text { Count }\end{array}$ & Researcher & University & $\begin{array}{c}\text { Adjusted } \\
\text { Count }\end{array}$ & $\begin{array}{c}\text { Normal } \\
\text { Count }\end{array}$ \\
\hline Tam, Kar Yan & $\begin{array}{l}\text { Hong Kong } \\
\text { University of } \\
\text { Science and } \\
\text { Technology }\end{array}$ & 2.16 & 5 & Arnott, David & $\begin{array}{l}\text { Monash } \\
\text { University, }\end{array}$ & 2.00 & 2 \\
\hline Gregor, Shirley & $\begin{array}{l}\text { Australian } \\
\text { National } \\
\text { University }\end{array}$ & 2.00 & 3 & Wei, K. K. & $\begin{array}{l}\text { City University } \\
\text { of Hong Kong }\end{array}$ & 1.65 & 5 \\
\hline
\end{tabular}




\section{About the Author}

Aleck C. H. Lin is a PhD and Research Fellow at the Australian National University. He is a core member of the National Centre for Information Systems Research, Australia. Dr. Lin's research interests lay in the strategic development of information systems, multimedia and interactive information systems, human-computer interaction in knowledge spreading, and emotional computing.

Shirley Gregor is the ANU Endowed Chair in Information Systems at the Australian National University, Canberra, where she heads the National Centre for Information Systems Research. Professor Gregor's research interests include the adoption and strategic use of information and communications technologies, intelligent systems, human-computer interaction and the philosophy of technology. Professor Gregor spent a number of years in the computing industry in Australia and the United Kingdom before beginning an academic career. $\mathrm{Dr}$ Gregor's publications include publications in journals such as Management Information Systems Quarterly, Journal of the Association of Information Systems, European Journal of Information Systems, Journal of Strategic Information Systems and the International Journal of Human Computer Studies. Professor Gregor was made an Officer of the Order of Australia in the Queen's Birthday Honour's list in June 2005. 